\title{
INSIDE OUT:
}

Good, Evil, and the Question of Inspiration

Oliver Smith

\begin{abstract}
Russian atheism is by no means a conscious rejection, the fruit of a complex, agonizing and prolonged effort of the mind, the heart and the will, the product of personal experience. No, most often it is taken on faith, and preserves the characteristics of a naive religious belief, only inside out.
\end{abstract}

-Sergei Bulgakov

Sir, didst not thou sow good seed in thy field? From whence then hath it tares?

-Matthew 13:27

Perhaps the most fundamental theme running through the Vekhi collection is the division between inner and outer, internal and external. The "common platform" of all the authors, Mikhail Gershenzon tells the reader in his "Preface," is "the recognition of the theoretical and practical primacy of spiritual life over the external forms of community," with an emphasis on the "individual's inner life" (xxxvii). ${ }^{1}$ This division between internal and external appears in one form or another in all of the essays. It can be observed in the critique of the Russian intelligentsia's alleged propensity for disregarding the internal work of personal development in favor of external social engineering; its inability to digest ideas or beliefs rather than simply gathering, herd-like, under the latest flag; and its dependence on external might over inner, spiritual reserve. ${ }^{2}$ The tendency of the Russian intelligent to, in Gershenzon's words, live "outside himself [vne sebia]" (51), ${ }^{3}$ 
is clearly one of the principal targets of the Vekhi critique. Not centered in himself and thus enjoying only minimal interaction with his inner life, the intelligent reads the reality around him in a similar vein. He admits of no causality but that of the material order, a causality that does not arise from a place of interiority but, so to speak, slips off the shapes of things, building its future from the mechanical flux of events. Change the flux of events-through ordering, or through the mechanical construction of society and nature, for example-and you are able to control the influx of good and evil into the world or, more precisely, radically to diminish the latter in favor of the former. "The basic philosopheme of socialism," writes Petr Struve, "its ideological axis as a world-view, is the principle that human good and evil ultimately depend on external conditions" (119).

This is all well-worn ground on which many subsequent critiques of the Soviet system, indeed of totalitarianism in general, have been founded. ${ }^{4}$ This essay concentrates on a somewhat different aspect of this inner-outer division, namely Sergei Bulgakov's at first puzzling categorization of the unconscious religiosity of the intelligentsia-a religiosity much debated in Vekhi, as indeed it was before and after-as one that shares all the features of naive faith, even Christian faith, excepting the fact that it is "inside out [naiznanku]" (22). This phrase will be explored in the context of the tradition on which the Vekhi essays self-consciously draw yet rarely articulate openly, namely that of the apocalyptic strand in Russian religious thinkers such as Fedor Bukharev, Fedor Dostoevskii, and Vladimir Solov'ev. While I seek to illuminate this problematic from the perspective of Vekhi as a whole, I concentrate in particular on Bulgakov, whose life trajectory was inextricably bound up with the Solov'evian legacy and whose oeuvre demonstrates (with the possible exception of Nikolai Berdiaev) the strongest development of eschatological themes, the culmination of which we see in his last complete work, Apokalipsis Ioanna (The Apocalypse of John, 1948). Through the prism of Bulgakov, I therefore seek to uncover a consistent hermeneutic that weaves through the pre- and post-revolutionary periods and encapsulates both Bulgakov's own evolving conception of the workings of good and evil in Russian society and the wider framework of apocalyptic interpretation in which it was set. 
It should be stated at the outset that a religiosity "turned inside out" does not for Bulgakov equate merely to a transposition of the object of faith from God to nothing, atheism replacing theism by an inversion of its object. Conventional wisdom has of course long taught that atheism requires just as much a leap of "faith" as belief in God does, yet this is the focus of neither Bulgakov nor the Vekhi authors as a whole. It is fair to say that they are only tangentially interested in the ideological structures underlying Russian atheism and in the patterns of belief that fuel atheistic currents of thought, which, as the authors point out, feed on many of the same tendencies as contemporary atheism in the west.

In a recent book on Dostoevskii, Rowan Williams writes against the grain of many commentators, arguing that the novelist was not concerned in solving the so-called "cursed questions," this being especially the case as regards the question of the existence or non-existence of God. Rather, he attempted to portray what a world without God might look like, and what it might mean for human beings to inhabit such a world. ${ }^{5}$ Atheism is not debunked as a matter of course; rather, its various, often ambiguous effects are traced through the actions of his protagonists. While the approach of the $V e k h i$ authors is clearly less creative and more explicitly philosophical, they nevertheless proceed in a similar manner: their goal is not to provide an alternative worldview to the atheistic nihilism, the "heroism," or whichever term we choose to use, of the revolutionaries, but to portray the effects of such a worldview on the "soul" of the intelligentsia. It is only insofar as they depict the effects of atheism on human life severed from absolute values that they can be seen to propose the means for the overcoming of atheism. Yet, whereas in his novel Besy (The Devils, 1872) Dostoevskii tends to read contemporary events as ciphers for a larger reality, drawing the shapes of the future from the still-uncertain present, the Vekhi essays work in the opposite direction. They move from the all-too-real to the murky source of inspiration in which the real had its birth. Where Dostoevskii may be described as constitutive and prophetic, Vekhi is primarily diagnostic: it attempts not to lay bare the partially concealed content of the soul of the Russian intelligentsia but to interpret the development of the same from its actual history, to read the signs of the disease from its manifestly evident symptoms. 
Nevertheless, Vekhi occupies a kind of liminal zone: its concrete time is a Russia poised between two revolutions. Its authors' reading of history, which is described by Bulgakov as "not mere chronology, relating the sequence of events," but "life experience, the experience of good and evil" (17), has therefore both a diagnostic and a prophetic aspect. On the one hand, that such experience had come to a head, and that, as a consequence, a kind of veil had dropped from the face of the Russian intelligentsia during the revolution of 1905, was axiomatic for the Vekhi authors. No longer was it a question of intuiting the darkness within; the darkness was there for all to see. For Bulgakov, the days of the revolution had revealed the "full-blown image of the intelligent" (21), while Struve speaks in almost identical terms: "the intelligentsia ... became fully manifest in the revolution of 190507" (118). Yet, on the other hand, the precise contours of this definitive revelation, for all its demonstrative power, appear to many readers of Vekhi to be particularly difficult to chart. This is in large part due to the fact that Vekhi is not primarily concerned, unlike its predecessor Problemy idealizma (Problems of Idealism, 1902), with the critique of philosophical and political systems; nor, unlike its successor Iz glubiny (Out of the Depths, 1918), is it focused on the study of a single historical event and its underlying causes. Read a hundred years after its publication, this series of essays "about the Russian intelligentsia" appears to its reader to be a bridge spanning its two sister volumes: it has neither the emotional detachment of the earlier nor the apocalyptic catastrophism of the later essays, yet it draws on the same wellspring that gave life to both.

While Out of the Depths appropriates the full force of biblical apocalypticism (its title being merely the most explicit self-representation of authors who, in the words of Struve, were all "undergoing a common torment"), ${ }^{6}$ the apocalyptic context of Vekhi exists mostly in veiled form. ${ }^{7}$ Struve, the editor of the later essays, spoke of Vekhi in the post-1917 landscape as "merely a timid diagnosis of the vices of Russia and a weak premonition of that moral and political catastrophe" ${ }^{8}$ which was to befall Russia. While Vekhi may not have quite the tragic purpose and feeling aroused by later events, Struve surely understates the import of the 1909 volume. Indeed, if one were to pick a biblical parallel for the continuity between the two volumes, one could do worse than comparing them to pre- and post-exilic 
Jeremiah. Vekhi, taken as a whole, is a particular form of jeremiad, a lament that singles out not only the sins of the present but also the fruit that may be reaped through the perpetuation of such $\sin .{ }^{9}$ It is this adumbration of a still uncertain future-far from timid in its discourse-that moves through Vekhi as a shadow-context on which the authors both consciously and unconsciously draw. ${ }^{10}$ In particular, the very liminality of the historical space in which it resides-the instability of the present moment-lends a portentous air to the essays' urgent appeal to turn inward. In this threshold time, the emergence and propagation of evil is predicated not on historical events or movements but on the quality of the inner life of individuals, and the personal relations between them that constitute society. Good and evil are borne not somewhere in the ether but within concrete persons, and it is the contention of Vekhi that the Russian intelligentsia, as a social body, has become a dangerous incubator of a virulent spiritual malaise whose maturing fruit is envisaged in apocalyptic terms.

A comment made by Semen Frank gives us the most concise expression of the Vekhi perspective on what had happened in their recent historical past: the "most tragic," he writes, "and, on a superficial level, surprising development [s vneshnei storony neozhidannyi fakt] of our recent cultural history" is that "subjectively pure, disinterested, self-sacrificing devotees of the social faith turned out to be not only the political allies but the spiritual kin of robbers, murderers, hoodlums and debauchees" (153). ${ }^{11}$ The words "on a superficial level, surprising development" (alternatively, "unexpected fact from an external perspective"), arrest our attention here. How could it be that the conscious and unconscious religious aspects of the intelligentsia to which each author points-Berdiaev's "thirst for justice on earth that is rooted in the soul of the Russian intelligentsia" (7), Bulgakov's "eschatological dream of the City of God and the future reign of justice" (21), Frank's "spontaneous sense of vital love for people" (141), those defining characteristics that draw the Russian intelligentsia so close to authentic, religious maximalism (podvizhnichestvo) - could not only be corrupted but corrupted so definitively and so absolutely? In Bulgakov's words from the dialogues that were included in the collection Out of the Depths of 1918: "There occurred some kind of black transfiguration: the people of God became a herd of Gerasene swine." ${ }^{12}$ Apparent good somehow mutated into 
manifest evil in the blink of an eye, and it is the nature, foundation, and consequences of this transformation that the Vekhi authors are at such pains to disclose.

For the Vekhi authors, the answer to the dark riddle of Russian revolutionary experience does not lie in the prevalence of certain worldviews-atheism, nihilism, materialism, and the rest. Such trends existed in the west, as Bulgakov, Struve, and others point out, often in just as emphatic a form. Nor does the answer lie in the historical fruit of these worldviews, in this case revolution. "Revolution, meaning certain political actions," writes Bulgakov, "does not in itself predetermine the specific spirit and ideals that inspire it" (38). Political uprisings, even revolutions, are not in themselves evil. The Vekhi contributors are very far from the political reactionaries they were sometimes painted to be. The source of evil, according to them, should rather be sought in the nature of the human possession of these ideals, the enervating spirit of the revolution, the inspiration that lurks behind the flag-waving of countless "-isms" and political maneuverings. But for Bulgakov and others, it is the character of this inspiration which is so hard to pin down. Even when they read back from its manifestations in Russian reality-criminality, violence, hatred-it is still hard to locate the point of departure from where the rot began.

This may explain one of the indicative rhetorical devices of Vekhi: metaphors of clothing and dress, Bulgakov's "inside out" being no exception. The effect of veiling or distorting the appearance of something is to mislead and confuse. Comparing German and Russian students, Aleksandr Izgoev writes that though the former "gets drunk, cracks stupid jokes, and behaves outrageously," he does not "array his drunken cavorting in the elegant garb of Weltschmerz" (79). In a similar vein, Berdiaev talks about the intelligentsia dressing in "the European garb of Marxism" (4). Struve suggests that Herzen "sometimes wore the uniform, as it were, of the Russian intelligent" (121), and Frank uses the same word "uniform [mundir]" as Struve to talk about living people who have "garbed their soul in the intelligent's moral uniform" (137). These metaphors relate, in part, to the superficial absorption of western ideas by Russian intellectuals, whereby ideals and philosophical trends were "signed up to" unreflectively without any inner movement on the part of their holders-pure "fanaticism," as Berdiaev puts it (14). 
Were these sartorial metaphors no more than a commentary on the superficiality of the Russian reception of ideas, however, their role in engendering the kind of urgency the Vekhi contributors wished to inculcate in their readers would not be nearly so great. A good deal of that urgency, so clearly felt even from a century's distance, derives from the fact that these metaphors of veiling and unveiling, of disguise and impostorship, draw, whether self-consciously or otherwise, on the apocalyptic tradition of past Russian thought. Here the question of the quality of the political and philosophical culture of Russia is supplemented by wider questions governing the nature of good and evil, their interaction within the human heart, and their final resolution in a suprahistorical landscape. This overlaying of a larger and more comprehensive narrative atop of the Vekhi critique of contemporary societal ills comes into greater focus when set against the background of the apocalyptic imaginings of two particular thinkers, Bukharev and Solov'ev, whose own, peculiar interpretations of the two apocalyptic books of the Bible-Daniel and Revelation-are particularly instructive to consider in this regard.

In 1860, Bukharev published a work entitled O pravoslavii v otnoshenii $k$ sovremennosti (On Orthodoxy in Relation to the Contemporary World), which sought to practice a kind of biblical exegesis that could be applied not only to questions of doctrine or historical context but also to the most pressing problems of modernity. In the fourth and final chapter, he offers an interpretation of the prophet Daniel's vision of the Four Beasts (Daniel 7:2-8). ${ }^{13}$ The vision is complex, but what Bukharev plays on is the element in it that endows the beasts with human characteristics. The lion is, according to the biblical passage, "lifted up from the ground and made to stand on two feet like a human being; and a human mind is given to it," and on the small horn that emerges from the final beast there appear "eyes like human eyes." The repetition of the word "like," with an emphasis on semblance and appearance, occurs in the vision as a matter of course. The fact that the beast does not have human eyes but "eyes like human eyes" resonates with Gershenzon's description of the intelligentsia in Vekhi as "man-like monsters" (61). ${ }^{14}$ Bukharev employs these human characteristics of the beasts to construct a new series of human and humane concerns that broadly correspond with many of the Russian intelligentsia's most 
cherished ideals, transferring the vision from the remote environment of Babylonian mythology to a context rich in contemporary resonance:

Even though [a person] concern himself with the maintenance of human rights, even though he spend his time reasoning as to how to elevate human dignity, reason and the human heart, yet does not do so in the manner of Christ, the Son of God, his principle will still be the beast, even though it has "eyes like the eyes of man." [...] Even though this person, who does not value conformity to the Son of God himself, be distinguished by a multi-faceted education, even if he be in our time as a Hellene had been before a barbarian in the ancient world-alas, in his motivations we still do not see a human being but only the image of a lynx or a leopard, attractive to the eye and no more. ${ }^{15}$

Bukharev is indicating that the presence of the most laudable, perhaps even ethically unavoidable, ideals without an inner conformity to the principle of authentic humanity-Christ, the Son of God-may not only mask the hypocrisy of the actor but itself represent the sign of the beast. The principle of humanity-the carrier of the image of God in the world-does not arise from within but is conferred from without. "A human mind is given" to the beast, according to the Book of Daniel. This does not render the ideals that emerge evil or misguided: the criterion for their judgment lies not here but in the source of their birth, in the heart of the intelligentsia itself. However strong the moral imperative of each stated ideal from an objective perspective, therefore, they tell us nothing about the spirit of its adoption. Indeed, the Russian tradition holds that the most perfect expression of the religious ideal in word and action may mask the purest embodiment of evil. "The most profound meaning of world history," as Solov'ev said in February 1900 , "is the fact that in the final historical appearance of the evil principle there shall be such a great deal of good." ${ }^{16}$

Solov'ev, in whom the apocalyptic strand of Russian thought found its most compelling articulation, went on, in the introductory words to his public reading of Kratkaia povest' ob Antikhriste (A Short Story of the Antichrist, 1900), to give a kind of manifesto for the future incursion of evil in the world, leaning heavily, like the Vekhi authors who succeeded him, on the imagery of clothing. "It is required," he said, "that the prince of this world be allowed to show himself toward the end from the best angle, 
to become freely adorned in every semblance of good." ${ }^{17}$ In the context of the Vekhi debate regarding the religiosity of the intelligentsia, the question that emerges from Bukharev and Solov'ev's eschatology is this: does the semblance of authentic religious inspiration, the proximity of the soul of the intelligentsia to absolute good, act as a redeeming factor? Or is it, to the contrary, a sign of what Bulgakov terms a profound and irreconcilable "internal difference" in the face of "apparent, external, similarity" (24)? It was this point that divided the Vekhi authors: not the apparent religiosity of the intelligentsia, on which there was broad agreement, but the redemptive power of the same.

Solov'ev ended his reading of the short story that was to bewitch and puzzle many future Russian thinkers (in almost equal measure) with a short afterword, the first few sentences of which contain a summary of the intuition he wished to convey to his listeners: "Such is the impending and inevitable dénouement of world history. We shall not see it, but events of the not-too-distant future throw their prophetic shadow, and in our lifetimes more clearly and undeniably than ever do counterfeit good, fraudulent truth and fake beauty rise before our eyes. All the elements of the great deception are already before us, and our immediate descendants will see how all these things shall interweave and come together in one living and individual phenomenon, in Christ turned inside out [Khristos naiznanku], the Antichrist." ${ }^{18}$ The antichrist in Solov'ev's handling is not the archetypal villain but the great pretender, the agent provocateur who not only infiltrates the camp of the good but champions its cause: from cessation of wars to greater cooperation between the countries of the world to human and even animal rights. This is not the antipode to Christ but his mirror image-his projection in externality, endowed with the grand mannerisms of religiosity yet, to use Struve's words, "without the content" (125). Solov'ev's Antichrist is a Christ who has slipped into his opposite without even noticing it, as if this were a perfectly natural thing to do. He has adorned himself in the inner principle of human being, the Word-Logos, but he wears it inside out: instead of the turning to God through repentance and conversion of heart, there is a turning to the material world, to the surface of things. The ideals that animate him rise not from the intimate places of the soul but are entirely self-posited: they do not penetrate the surface of things since they 
themselves derive from the surface. The interior content is spent wholly in externality, without remainder: in moralizing, in social construction, in the search for worldly over spiritual power, and in an excess of gesture and posturing.

If we concentrate on the character of Solov'ev's Antichrist alone, however, we miss the full picture. The Antichrist does not appear out of nowhere-his advent is heralded by the spread of what Solov'ev calls "counterfeit good, fraudulent truth and fake beauty." He is very much a product of his time. And what is striking about the Vekhi critique of the consciousness of the intelligentsia is the prevalence of the theme of perverted ideals and norms in their historical appraisal of the ills of modernity. In each human activity the authors choose to dwell on, they intuit a perversion of its ideal purpose and character. In the search for truth, instead of the use of reason to integrate and make sense of the things of the world, Gershenzon sees an empty moralizing (rezonerstvo), a "morbid self-analysis, a ceaseless and senseless digging in the soul" that "deforms the natural features of things, and deprives them of their essential nature." Instead of a living "legal conviction," Bogdan Kistiakovskii sees a slavish bowing to law as to a coercive force. Instead of the consciousness of the Christian ascetic (podvizhnik), Bulgakov sees the revolutionary hero, mangodhood rather than Godmanhood.

Faced with this mass of perverted ideals, the Vekhi authors look for a measure of authenticity: a conscious or unconscious trait in the Russian intelligentsia that holds out a promise of redemption. Frank finds such a trait in the "spontaneous sense of vital love for people" that at any given moment of its historical existence saves the intelligentsia from diving into the abyss, the "one thing" that "atoned" for everything else (141). Many of the Vekhi authors stress this commitment to selfsacrifice, the kenotic strain in the psychology of the Russian intelligentsia of active self-giving in love, which constitutes a central part of their religiosity. ${ }^{19}$

But what if even love itself can be corrupted? What if there is a form of self-giving that, far from affirming the other, weighs it down and deprives it of its essential nature? It is this possibility that Bulgakov explores five years after the publication of Vekhi in a 1914 article on Dostoevskii's The Devils, 
which adds the final component to his reflections on the adaptability of evil in taking on the form of the good.

Describing the love that exists between Stavrogin and Lise, he writes:

These are not the wings with which the soul soars into the eternal blue of the heavens. These are fetters, demonic charms. This is love turned inside out [liubov' naiznanku], love-hate, which also possesses a certain clarity of vision, only not of good but of evil, seeing in the beloved and, at the same time, hated person not a creation of divine love but the spoils of hell. ${ }^{20}$

Here is a love that does not free but imprisons, a love that in its practice has dissolved in its opposite. Bulgakov's description of such satanic love enables us to complete the three potential stages of the great deceit. We have, first, the general mind-set of the intelligentsia: religiosity turned inside out, mangodhood rather than Godmanhood; second, the activity that results from this mind-set on society and the world around it: love turned inside out, love-hate; and third, the final, individual embodiment of both: Christ turned inside out, the mangod, Antichrist. In each stage, the perversion of the ideal does not present us, at least not until the final unmasking, with a transformation of good into evil, accompanied by the gradual, or even sudden, extinguishing of the former. Rather, it is the undifferentiated presence of the two poles at a single point, or in a continuum where their differentiation loses all its meaning. As Williams has written in the context of The Devils: "The recording of events as a single continuum without value and continuation leaves us with a mangled idea of freedom and even of truthfulness. If all we have before us is a continuum which includes equally horror and beauty, the horror is worse than it would otherwise be because there is no way of putting it into a context where it can be healed or modified. It just happens." ${ }^{21}$ It is the reality of such a continuum that Dostoevskii portrays in the character of Stavrogin, whose very name expresses the presence of the two poles in one individual-the cross (Greek: stavros) and the apocalyptic horn (Russian: rog) of Daniel-and whose ascent to his death in a loft-attic encapsulates the fates of both Christ and Judas. ${ }^{22}$ Stavrogin leads people to their dooms through advocating any number of ideals classifiable under various -isms; yet these ideals come from a place of absolute indifference: they belong not to him but to the grey matrix of this 
indifference. "How I wish you were hot or cold," quotes Tikhon to him from Revelation, "but as you are lukewarm, I will spit you out of my mouth."23

Recalling Dostoevskii's famous epigraph to Brat'ia Karamazovy (The Brothers Karamazov, 1880), "Here God battles with the devil, and the battleground is the human heart," the problem of Stavrogin takes on an additional dimension. What he represents is not the epitome of evil but the absence of any kind of battle between the warring principles, which in its own way is more terrifying. The battle that takes place within his soul continues, as it does in every living soul, but Stavrogin does not actualize it, since his will does not, cannot, give assent to the choice of either good or evil, instead resting in absolute indiscrimination. And without that battle, the human person, argues Bulgakov, itself not being evil since it is made in the image of God, becomes a channel for evil: it literally ceases to exist, or slips into non-being. Bulgakov here talks of the "absence of the living Stavrogin, his existence as mask [lichinnost']." ${ }^{24}$ The outer form persists as a hollow shell, and it is the inspiration of this mask that gives birth to the pseudo-religious transformation of the characters that surround him: to the mangodhood of Kirillov, the God-bearing nationalism of Shatov, and the murderous nihilism of Verkhovenskii. The triune arc of deification according to the Christian model-God, humanity, world, where the energies of God are channelled through humanity onto society and the world around it-is here fundamentally transformed. Humanity and God shift places: Godmanhood is replaced by mangodhood. The human form, divested of its belonging to God at its innermost core, wears its God-bearing interiority on the outside, and seeks to use its own external words, actions, and thoughts to deify its environment. Yet what is deified in the process is sheer emptiness, a form with no content, the absent humanity of Stavrogin. This absence begets not a form of Prometheanism - a rebellion against God and the ways of God-but rather the loss of religious consciousness per se, the elimination of any residual significance that the terms "good" and "evil" might once have had.

It is the fear of such an outcome that is expressed by Bulgakov in Out of the Depths through the mouth of the social activist: "If only our people were theomachists, mutineers against all that is sacred; this at least would constitute a negative self-testament of their religious spirit. More often than 
not, though, they simply behave as louts and cattle who have nothing to do with faith whatsoever. As if there were no demons in them at all, for what would demons do with them? From demonic possession one can be healed, but not from bestiality." 25 Such bestial indifference eats away at core human attributes such as belonging, loyalty, and responsibility. Here the goal becomes not internal participation in events but the provoking of certain external effects in those around you, for no other purpose than the simple possibility of so doing.

In his essay on The Devils, Bulgakov states that Dostoevski had "treated in artistic terms the question of political provocation, understood not only in a political sense but in a more profound, experiential-religious sense." ${ }^{26}$ From Stavrogin, whom Bulgakov terms a "spiritual provocateur," there emerges "the provocateur-betrayer, the 'colleague' who gives away the secrets of the party for money. [He is] a degeneration of this type, its reverse side, or its elaboration and pollution, though most probably inevitable." ${ }^{27}$ The degeneration of the more complex figure of Stavrogin into a political chameleon brings to mind a figure whose shadow is cast across the Vekhi essays: Evno Azef, whom Izgoev describes as the "foremost hero of the day" (83), and who indeed conforms like no other to all that Bulgakov has to say on the nature of revolutionary heroism.

A double-agent and provocateur, Azef was involved in terrorist acts for the Social Revolutionaries while at the same time informing on his colleagues in his role as spy for the Okhrana, the Imperial secret police. Although much doubt has recently been cast on his actual character and activities, ${ }^{28}$ what is clear is that by the time of the writing of Vekhi, barely a month after his unmasking in February 1909, he had become a sort of cipher, a receptacle into whom Russian idealist philosophers poured the eschatological forebodings of the thinkers of the past century. "Is AzefVerkhovenskii," asked Bulgakov, putting together his name with one of Stavrogin's spiritual children, "and azefshchina as a whole merely a chance phenomenon in the history of the Revolution, an abnormal growth that may never have been? Or can we see in it, to the contrary, its core spiritual disease?"29 In his essay for Vekhi, Bulgakov highlights the moment of personal discernment in the case of Azef, when you can "no longer tell where the revolutionary ends and the police agent or provocateur begins" 
(32). Azef can be seen, and was certainly so interpreted, as the historical fulfillment of the apocalyptic incarnation of evil as interpreted by Russian thinkers. A resident of two worlds, with strong links to neither yet ready to give himself in service to either one, Azef exists on the same continuum as Bukharev's beast, Solov'ev's Antichrist, and Dostoevskii's Stavrogin. He is both betrayed and betrayer, yet exists in this contradiction in absolute indifference. In the evocative words of Vasilii Rozanov, "it was decided to crush the Christ of the Revolution by the Judas of that selfsame Revolution: to open wide the garment of Christ and under it reveal Judas." ${ }^{30}$

Yet the question here is not only about the mark of the beast-the character of evil's appearance in the world-but about the kind of society that facilitates such an appearance. "Azef was some kind of unique monster, and the names 'satan' and 'satanic' were often pronounced alongside his name," wrote Rozanov. ${ }^{31}$ For the latter, however, the most incredible thing was not that this monster existed, but that he could have been believed for so long. "The whole matter rests in the inability to perceive," he wrote in a response to Vekhi. The revolutionaries "knew his uniform but did not know his soul." 32 Great deception can only work on those who are spiritually unequipped for its possibility. The uniform fooled them precisely because they had physical eyes, but not spiritual ones.

It was to the nature of spiritual discernment in the apocalyptic context of post-revolutionary Russia that Bulgakov would dedicate much of his later writing. In 1931, he returned to the theme of betrayal and redemption in an essay on Judas Iscariot. His major concern in this piece is not to condemn the sin of the archetypal betrayer, nor is it to offer a moralistic teaching on the corruptibility of good intention. Rather, he attempts to disclose the "mystery of Christ and Judas" as a certain "hieroglyph of fate," and the reader is left in no doubt that the fate he has in mind is that of the Russian nation. ${ }^{33}$ "The tragedy of the apostle-betrayer, his terrible fate, stands before us with imploring eyes. It has become now our own fate, not personal, but national." ${ }^{34}$ Each one of the characteristics with which he, alongside other intellectuals of the Russian diaspora, had characterized the Russian intelligentsia are here ascribed to Judas, who is described as a "monomaniac [odnodum]," a person "blinded by utopia" who above all "needed a task" to which to dedicate himself. ${ }^{35}$ 
Bulgakov is no longer trying to warn of the adaptability of evil to all semblances of good, as did Solov'ev and Bukharev in the century before him, but instead to reveal the apostle in the betrayer, and the betrayer in the apostle, in such a way that neither dissolves in the other, both remaining as aspects of an antinomy that is never subsumed in identity. It is an attempt, it may be suggested, to understand the Christ-Judas mystery-the ultimate crux theologiae according to Bulgakov-sacramentally, as the very economy of the Gospel, the inner spring on which all else rests. The atheistic movement in Soviet Russia is here interpreted as neither anti-religious nor pseudoreligious at first, but as a moment in the soul of a nation which can only be fully comprehended when taken in the fullness of its linkages with historical time. One needs, wrote Bulgakov, "to understand the contradictions in the Russian soul in their connection, as the disclosure of one whole, linking the past with the present and the future." ${ }^{36}$ For Bulgakov, only in so doing could one intuit that this "diseased love for Christ, this struggle against Christ in the name of the truth of Christ" is actually "titanic, that is, simultaneously heroic and demonic." ${ }^{37}$ Just as God sends Judas on his path of misery "in order to lead him to redemption," 38 "in the Christ-murdering hearts and souls of Russia there is concealed Christ's Resurrection." ${ }^{39}$ This may be wishful thinking, born of desperation; there may even be something to Ivan Il'in's accusation that Bulgakov had spoken "in defense of Judas the Betrayer in an attempt to proclaim him the patron saint of the Russian people (for 'we too have betrayed Christ')."40 Bulgakov, however, is not trying to force a silver lining onto the most inappropriate of rainclouds. His is not the facile mission of the theodicists against whom Vissarion Belinskii spoke so forcibly at the beginning of the Russian intelligentsia's path to selfdiscovery. ${ }^{41}$ Suffering and evil are not justified through their involvement in a narrative or sophistic dialectic which will supposedly result in the triumph of the good. Nor is Bulgakov's view wholly aligned to that of his fellow Vekhi contributor Berdiaev, who in his 1923 work Novoe srednevekove (The New Middle Ages) depicted European civilization as having removed itself altogether from the battle between good and evil through a kind of inner banality, arguing that "Russia would rather give birth to the antichrist than to a humanistic democracy and neutral humanistic culture." ${ }^{42}$ The antiChristian values of a Soviet-style regime are not, in Bulgakov's view, by 
some mystical proximity in distance closer to authentic Christianity than are the values of a secular society which has lost a sense of both divine and demonic. Indeed, as we have seen, it was the absoluteness of such a lossthe lukewarmness of Stavrogin, the abolition of any distinction between good and evil-that he regarded as the essence of the Russian condition. Instead, he saw the revolution in Russia as an unprecedented call to an entire nation to turn away from outward planning toward the only place that remained: the interior space of authentic humanity. This call was not closer to its desired destination by virtue of its residence at the opposite pole. But it was more pressing because of the radical nature of the choice facing Russia and the Russian intelligentsia.

In his contribution to Out of the Depths, Sergei Askol'dov draws on the Parable of the Tares from the Gospel of Matthew (Matthew 13:24-30) to paint a picture of the contemporary state of the Russian nation:

In all this great fortitude, in the non-acceptance of evil inside one's soul, in the practical resistance to it, alongside the crafts of evil-indeed already in some ways differentiating themselves from these-are there not maturing in the people's soul yet other holy crafts for that battle which will take place in the final days, in those days when to take part in the antichristic state will be an unforgivable sin, a definitive alignment under the banner of the enemy of Christ? So alongside the choking tares there grows good wheat, the number of the righteous is continually being renewed, and the spiritual qualities needed for the creation of the new organism of the Kingdom of God are coalescing. ${ }^{43}$

Askol'dov's choice of biblical allusion is not accidental, and it illuminates the particular constellation of Christian eschatology and Russian experience that lurks behind so many of the earlier arguments of the Vekhi authors. The word translated into English as "tares" (in modern translations, "weeds") refers to the plant commonly known as darnel (Lolium temulentum), whose seeds are sown amongst the good (wheat) seeds by an enemy "while everybody was asleep" (13:25). Darnel is so like wheat in appearance that in the early stages of its growth it is all but indistinguishable from the genuine article. ${ }^{44}$ There is no external criterion fully capable of telling them apart, just as is the case for the good and ill of the Russian revolution. Through its description of the growth of the wheat alongside the darnel, the parable 
introduces, in the words of the contemporary theologian Robert Capon, a parallel insistence on the cosmic reach of God's kingdom and what he calls the "catholicity of evil [...] the radical intermixture of goodness and badness in the world." ${ }^{55}$ Moreover, unlike other Gospel parables of judgment, the ground is not nurtured for the production of evil, which appears as if from nowhere: "There is no openness here, none of the simplicity that characterizes the straightforward hostility of the birds or the rocky ground or the thorns. Rather, there is the full-blown paradox of the appearance of evil in a situation where there is absolutely no reason to expect it." ${ }^{36}$ These words bring to mind once more Frank's bewilderment at the peculiar convergence of selfless revolutionary and callous murderer in the events of 1905, which were "on a superficial level [s vneshnei storony]" a "surprising development" (153). How could this occur? Who is to blame? According to the parable, the bad seed is sown by an enemy who works while the laborers are sleeping, and it is this sleep, not the conscious intentions or even unconscious urges of the sowers, that facilitates the incursion of evil onto the land. In the interpretation of Filaret, Metropolitan of Moscow, sleep in this context means "carelessness and a lack of vigilant attention both to oneself and one's actions." ${ }^{37}$ It is this "sleep" from which the Vekhi authors wish to awaken their readers, in order to direct them once more toward the imperatives of constant self-judgment, self-questioning, and self-doubt.

Vekhi was a call to regain a sense of human involvement in the history of a nation, and a world, that avoided the extremes of absolute control and absolute helplessness. Its demand for a return to fostering inner life-in Bulgakov's words, for the intelligentsia to "be corrected not from without but from within" (34), should be seen not only in the context of a return to traditional values, to the prerogatives of personal spirituality over external organization, but also in the sense of a re-equipping for the spiritual struggle that continues without human intervention, yet which will not be decided without it. 
1 Quotations from Vekhi in English, and their page references, are taken from Marshall S. Shatz and Judith E. Zimmerman, eds. and trans., Vekhi/Landmarks: A Collection of Articles about the Russian Intelligentsia (Armonk, NY: M. E. Sharpe, 1994).

2 It may be suggested that Kistiakovskii is an exception to this trend. Yet, although his essay aims to counter the Slavophile view that whereas to the west belongs the way of "external truth, the truth of the state," to the Russians belongs the way of "inner truth," his ultimate view is that the Russian relationship to law is as to something exclusively external, as "coercive law" rather than "legal conviction" $(95,107)$.

3 References to the original Russian text of Vekhi, and quotations from Iz glubiny (Out of the Depths), are taken from V. V. Sapov, ed., Manifesty russkogo idealizma (Moscow: Astrel', 2009), here 509.

4 Ol'ga Sedakova, one of the most penetrating critics of contemporary Russia, echoes the premonitions of Vekhi from the perspective of one who has lived through the horrors of the last century. "It seems to me," she said in a recent lecture, "that if the twentieth century has taught us anything, it is that it is no longer possible to offer up any kind of universal projects.... There is but one solution: the personal turning of each individual toward their very selves, toward their inner person." See Ol'ga Sedakova, "Posredstvennost' kak sotsial'naia opasnost," in Posredstvennost' kak sotsial'naia opasnost': sbornik (Moscow: Magistr, 2011). Electronic version available at http:// www.intelros.org/lib/statyi/sedakova2.htm.

5 Rowan Williams, Dostoevsky: Language, Faith and Fiction (London: Continuum, 2008), 4-5.

6 Sapov, Manifesty russkogo idealizma, 635.

7 Robin Aizlewood calls Out of the Depths a "reprise" of Vekhi "in apocalyptic mode." See R. Aizlewood, "Besy', Disorientation and the Person," Slavonic and East European Review 88, no. 1-2 (2010): 291.

8 Sapov, Manifesty russkogo idealizma, 635.

9 In 1911, Lenin spoke of the two great obstacles facing the regrouping of the proletariat around the revolutionary cause as "Stolypin's gallows and the Vekhi jeremiads [vekhovskie ieremiady]." Although the word here had the same negative connotations it had acquired in the English language, the resonance is nevertheless telling. See V. I. Lenin, "Razviazka partiinogo krizisa," Polnoe sobranie sochinenii (Moscow: Gos. izd. pol. lit.,1955), vol. 21, 1.

10 Vekhi's discourse, as Aizlewood has pointed out, "best adumbrates the apocalyptic mood that pervades Iz glubiny." Aizlewood, “'Besy', Disorientation and the Person," 299.

11 For an account of the looting, mindless vandalism, and violence that followed the Revolution, see Orlando Figes, A People's Tragedy: The Russian Revolution: 1891-1924 (London: Jonathan Cape, 1996), 520-35.

12 Sapov, Manifesty russkogo idealizma, 707. See also the similar statement from the third dialogue: "Where there once rose a grandiose temple, there suddenly appeared only fetid, slimy, putrid dirt." Ibid., 727. 
13 Daniel 7:2-8. The vision includes a lion, a bear, a leopard and a beast so monstrous that the prophet has no name for it. For a history of the interpretation of the vision, see John Collins, Daniel: With an Introduction to Apocalyptic Literature (Grand Rapids, MI: Eerdmans, 1984), 74-83.

14 In an interesting passage, the Writer from Bulgakov's dialogues in Out of the Depths combines this vision of apocalyptic dehumanization with its concomitant militarization: "See how even the appearance of the soldier has changed. He has become somehow bestial, terrifying, particularly the sailor. I admit that these 'comrades' sometimes seem to me creatures wholly devoid of spirit and possessed only of the lower mental faculties, a particular species of Darwinian monkey-homo socialisticus." Sapov, Manifesty russkogo idealizma, 714.

15 Fedor Bukharev, O pravoslavii v otnoshenii k sovremennosti (St. Petersburg: Strannik, 1860), 307.

16 Cited in Nikolai Kotrelev, "Eskhatologiia u Vladimira Solov'eva (k istorii 'Trekh razgovorov')," in Eskhatologicheskii sbornik, ed. D. Andreev (St. Petersburg: Aleteia, 2006), 253.

17 Ibid.

18 Ibid.

19 The kenotic aspect of the Russian intelligentsia has been stressed many times in academic literature. See, for example, Marc Raeff, The Origins of the Russian Intelligentsia: The Eighteenth-Century Nobility (New York: Harbinger, 1966), 162-64.

20 Bulgakov, "Russkaia tragediia," in Sochineniia, 2 vols. (Moscow: Nauka, 1993), vol. 2, 511.

21 Williams, Dostoevsky: Language, Faith and Fiction, 73.

22 See Lena Silard, "Svoeobrazie motivnoi struktury Besov," Dostoevsky Studies 4 (1983): 159-60. Note also Hippolytus of Rome's association of the little horn that sprouts amidst the other horns of the final beast in Daniel's vision with the antichrist, and the stone that strikes the statue in Daniel 2 with Christ: "The other little horn that grows up among them meant the Antichrist in their midst; the stone that smites the earth and brings judgment upon the world was Christ." Hippolytus, "Treatise on Christ and the Antichrist," in The Writings of Hippolytus, Bishop of Portus: Fragments of Writings of the Third Century, 2 vols. (Edinburgh: T. \& T. Clark, 1869), vol. 2, 18.

23 Revelation 3:16. See Fedor Dostoevskii, Polnoe sobranie sochinenii (Leningrad: Nauka, 1974), vol. 11, 11.

24 Bulgakov, "Russkaia tragediia," 502.

25 Sapov, Manifesty russkogo idealizma, 728.

26 Bulgakov, “Russkaia tragediia,” 505.

27 Ibid., 521.

28 See, especially, A. Geifman, Entangled in Terror: The Azef Affair and the Russian Revolution (Wilmington, DE: Scholarly Resources, 2000). 
29 Bulgakov, "Russkaia tragediia," 523.

30 Vasilii Rozanov, “Zagadki russkoi provokatsii. Ocherk," in Sobranie sochinenii. Zagadki russkoi provokatsii, ed. A. Nikoliukin (Moscow: Respublika, 2004), 76.

31 Vasilii Rozanov, "Mezhdu Azefom i 'Vekhami"' in Sobranie sochinenii. Staraia i molodaia Rossiia (Stat'i i ocherki 1909 g.), ed. A. Nikoliukin (Moscow: Respublika, 2004), 266.

32 Rozanov, "Zagadki russkoi provokatsii," 74.

33 Sergii Bulgakov, “Iuda Iskariot-apostol-predatel"' in Put' parizhskogo bogosloviia (Moscow: Izdatel'stvo khrama sviatoi muchenitsy Tat'iany, 2007), 294, 353.

34 Ibid., 353.

35 Ibid., 315-16. Compare this to Berdiaev's diagnosis of the intelligentsia's disease in Vekhi: "Moral pathos degenerates into monomania" (7).

36 Bugakov, "Iuda Iskariot," 354.

37 Ibid., 359.

38 Ibid., 322.

39 Ibid., 363.

40 Ivan Il'in, “Arkhimandritu Konstantinu <28.VI.1951>," Pis'ma $k$ arkhimandritu Konstantinu (Kirillu Zaitsevu), at http://kaplun.narod.ru/ilyin.htm.

41 See especially the letters to Vasilii Botkin in Vissarion Belinskii, Izbrannye filosofskie sochineniia (Moscow: Gos. izdat. pol. lit., 1948), 558-98.

42 Nikolai Berdiaev, Smysl istorii. Novoe srednevekov'e (Moscow: Kanon, 2002), 231.

43 Sapov, Manifesty russkogo idealizma, 669.

44 In rabbinic tradition, darnel is called "false wheat," and its emergence is connected with the generation of the Flood, when "even the earth acted lewdly; wheat was sown and it produced pseudo-wheat." See Midrash Rabbah, 10 vols. (London: Soncino Press, 1961), vol. 1, 28.8, 229.

45 R. F. Capon, Kingdom, Grace, Judgment: Paradox, Outrage, and Vindication in the Parables of Jesus (Grand Rapids, MI: Eerdmans, 2002), 94.

46 Ibid., 95.

47 Filaret, Sviatitel, Mitropolit Moskovskii, "Beseda iz pritchi o plevelakh," in Slova i rechi, 4 vols. (Moscow: Novospaskii monastyr', 2005), vol. 2, 239. 